\title{
KREATIVITAS JONET SRI KUNCORO DALAM KARYA TARI AMBABAR BATIK
}

\author{
R.Aj Roliska Kusumo Wardani \\ Institut Seni Indonesia (ISI) Surakarta \\ Jalan Ki Hadjar Dewantara No. 19 Kentingan, Jebres, Surakarta 57126 \\ Soemaryatmi \\ Institut Seni Indonesia (ISI) Surakarta
}

\begin{abstract}
Abstrak
Karya Tari Ambabar Batik merupakan koreografi kelompok yang terinspirasi dari corak - corak kain Batik. Peemasalahan yang diambil adalah elemen-elemen koreografi Karya Tari Ambabar Batik dan kreativiitas Jonet Sri Kuncoro dalam menciptakan karya tari Ambabar Batik. Konsep yang digunakan untuk menganalisis koreografi karya tari Ambabar Batik adalah konsep dari Sumandyo Hadi tentang elemen-elemen koreografi kelompok yang terbagi menjadi sebelas unsur yaitu: 1) gerak tari;2) ruang tari;3) iringan tari; 4) judul tari; 5) tema tari; 6) tipe/jenis/sifat tari; 7) mode penyajian; 8) jumlah penari dan jenis kelamin; 9) rias dan busana; 10) tata cahaya; 11) properti tari dan perlengkapan lainnya. Untuk mengupas kreativitas Jonet Sri Kuncoro dalam karya tari Ambabar Batik menggunakan teori 4P's dari Rhodes yang diungkapkan oleh Utami Munandar yaitu pribadi kreatif, pendorong kreatif, proses kreatif, serta produk kreatif. Hasil menunjukan Ambabar Batik merupakan pengungkapan dari ide yang diambil dari fenomena yang ada di Indonesia sebagi koreografi kelompok yang ditarikan sembilan penari. Koreografi yang tidak lepas dari kreativitas koreografer meliputi pribadi, pendorong dan proses kerja koreografer. Penelitian ini bertujuan mendeskripsikan dan menjelaskan tentang koreografi dan kreativitas tari Ambabar Batik karya Jonet Sri Kuncoro. Penelitian ini menggunakan metode pemelitian kualitatif deskriptif analitis. Simpulan dari penelitian ini menunjukan bahwa pengungkapan bentuk koreografi tidak lepas dari kekuatan pengalaman koreografer sebagai sebuah bentuk kreativitas.
\end{abstract}

Kata kunci: Ambabar Batik, Kreativitas, Koreografi, Jonet Sri Kuncoro.

\section{Abstract}

Ambabar Batik Dance is a group choreography that is inspired by Batik fabric. Problems taken are the elements of choreography Ambabar Batik Dance and the creativity of Jonet Sri Kuncoro in creating works of Ambabar Batik dance. The concept used to analyze the choreography of Ambabar Batik dance is the concept of SumandyoHadi, which is about the elements of group choreography which is divided into eleven elements, namely: 1) dance movement; 2) dance room; 3) dance accompaniment; 4) dance titles; 5) dance theme; 6) type / type ( nature of dance; 7) presentation mode; 8) number of dancers and sexes; 9) dressing and dress; 10) lighting; 11) Dance properties and other equipment. To explore the creativity of Jonet Sri Kuncoro in Ambabar Batik dance work, using the $4 P^{\prime}$ 's theory of Rhodes revealed by UtamiMunandar. That theory involves creative persons, creative booster, creative process, and creative product. The results show AmbabarBatik consists ideas taken from the phenomenon that exists in Indonesia as a choreographed group dance 
with nine dancers. There is choreography that cannot be separated from the creativity of the choreographer, including personal, choreographer and choreographer work process. This study aims to describe and explain about the choreography and creativity of Ambabar Batik dance by Jonet Sri Kuncoro. This research uses qualitative descriptive analytical method. The conclusion of this study shows that the disclosure of choreographic forms cannot be separated from the strength of the choreographer's experience as a form of creativity.

Keywords: Batik Ambabar, Creativity, Choreography, Jonet Sri Kuncoro.

\section{PENDAHULUAN}

Tari Ambabar Batik adalah sebuah karya tari yang mengagkat tentang motifmotif batik, karena batik adalah salah satu warisan bangsa yang harus dilestarikan. Batik yang kala itu sedang di promosikan oleh pemerintah untuk selalu dikenakan atau dipamerkan menjadikan dorongan koreografer untuk menciptakan karya ini. Koreografer yang juga dosen di Institut Seni Indonesia Surakarta ini ingin memperkenalkan motif batik kepada masyarakat khususnya anak - anak melalui media gerak. Koreografer berharap masyarakat lebih bisa menerima dan lebih mengenal motif - motif batik yang biasanya digunakan pada acara - acara formal maupun acara non formal.

Tari Ambabar Batik diciptakan oleh Jonet Sri Kuncoro pada tahun 2007, pertama kali dipentaskan di Sasono Langen Budaya, Taman Mini Indonesia Indah, Jakarta dalam acara Festival Parade Seni Tingkat Nasional. Jonet menciptakan karya tari ini awalnya untuk acara Festival Parade Seni Tingkat Nasional yang kala itu Provinsi Jawa Tengah memilih sanggar tari Soeryo Soemirat untuk mewakili dalam Festival tersebut.

Sanggar tari Soeryo Soemirat adalah salah satu sanggar tari yang ada di Surakarta, dan koreografer juga salah satu guru sanggar tersebut, karena adanya permintaan dari
Provinsi akhirnya Jonet memulai proses membuat karya tari ini. Karya ini ditarikan oleh sembilan penari perempuan yang pada kala itu masih tergolong usia anak - anak, Keputusan ini dibuat karena sanggar tari Soeryo Soemirat hanya mempunyai para siswa dan siswi yang masih tergolong anakanak, walaupun sebenarnya festival ini bukanlah untuk anak - anak tetapi Jonet sebagai koreografer tetap optimis untuk mengikuti festival parade seni tingkat nasional. Dalam festival ini terbukti bahwa karya tari Ambabar Batik mendapat beberapa penghargaan antara lain, sebagai penyaji unggulan, musik unggulan, penata tari unggulan, penata rias dan kostum unggulan. (Jonet Sri Kuncoro, Wawancara 4 September 2017).

Kehadiran karya tari ini dalam dunia seni tari semakin dikenal oleh masyarakat luas, terbukti jika karya tari Ambabar Batik ini menjadi salah satu icon dari Sanggar Tari Soeryo Soemirat.

Nama Ambabar Batik sendiri artinya adalah Bercerita Tentang Batik, yang dimaksut disini adalah pada karya tari ini Jonet memvisualisasikan karya tarinnya tentang anak - anak yang sedang bermain dengan kain bermotif batik dengan pola lanti yang disesuaikan kebutuhan panggung pementasan. Suatu fenomena yang menarik ketika dapat mengungkap proses kreatif Jonet Srikuncoro dalam karya tari Ambabar Batik, 
dilihat dari sisi pengeksplorassian properti yang tidak lain adalah kain batik. Selain itu, para penari yang masi tergolong anak - anak mampu menyajikan karya tari Ambabar Batik ini dengan baik. Berpijak dari uraian singkat tersebut peneliti akan mengungkap tentang penciptaan Karya Tari Ambabar Batik.

\section{PERJALANAN KESENIMANAN JONET SRI KUNCORO}

Seniman dalam ini merupakan pelaku seni yang dalam berkarya maupun melakukan aktivitas seni tidak luput dalam pengalamannya, demikian juga dengan seorang koreografer dalam berkarya sanggat dipengaruhi oleh pengalaman serta pengetahuan tentang tari. Pengetahuan itu didapat melalui melihat, belajar, melakukan aktivitas seni dalam hal ini menari dan akhirnya dapat membuat suatu karya tari dan melalui pengalaman berkesenian, koreografer maupun penari bisa mendapatkan hal baru yang belum pernah didapatkan sebelumnya. Pernyataan ini sesuai dengan pendapat Soedarsono bahwa berbagai seni muncul karena adanya kemauan yang ada pada diri manusia untuk mempelajari pandangan dari pengalaman hidupnya serta didasari atas kemauan dalam memberikan bentuk luar dari respon yang unik dan imajinasinya ke dalam bentuk yang nyata (Soedarsono, 1978: 38).

Jonet Sri Kuncoro adalah seorang pengajar tari di Sanggar Soeryo Soemirat dan dosen tari gagah di Institut Seni Indonesia (ISI) Surakarta. Pengalaman berkesenian Jonet Sri Kuncoro menjadi bekal dalam munyusun dan menciptakan karya - karya tarinya. Jonet Sri Kuncoro lahir pada tanggal 5 Desember 1963 di Kelurahan Panularan,
Kecamatan Laweyan, Surakarta. Jonet terlahir di lingkungan pemain wayang orang sriwedari. Hampir semua keluarganya bekerja menjadi pemain wayang orang.

Jonet mulai menari semenjak Taman Kanak-kanak (TK) ketika berumur 5 tahun. Pengalaman pertamanya dalam menari yaitu berperan menjadi Dayun di drama tari Menak Jingga, dan kakaknya menjadi Menak Jingga. Melihat ini pamannya yang bernama Waluyo seorang pemain wayang orang Sriwedari yang terkenal sebagai tokoh Anoman Plastik, mengajak jonet untuk mulai berlatih menari.

Latihan tari dimulai dari junjungan kaki, tanjak, sabetan, menirukan kakaknya dibelakang ketika sedang menari. Jonet dilahirkan dilingkungan wayang orang panggung, kehidupan keluarga sangat sederhana serba pas-pasan. Hidup yang sanggat sederhana membuat proses latihan tidak bisa menggunakan tape recorder sehingga dalam proses latihan dengan Waluyo hanya dengan menggunakan suara mulut yang menirukan suara gamelan dan sebuah korek api sebagai cempala (ketukan irama) untuk memberi aba-aba gerak tarinya. (Wawancara, Jonet 27 Oktober 2017). Tandatanda yang diberikan waluyo dalam melatih tari jonet seperti misalnya dhok $1 \mathrm{x}$ memberi aba-aba berdiri tanjak. Dhok dro dhok dhok memberi tanda untuk melakukan sabetan dan seterusnya. Setiap kali mendengarkan aba-aba dari Waluyo tersebut, secara otomatis Jonet segera siap untuk tanjak meskipun saat itu belum siap karena masih bermain dengan teman-temannya. Menari menggunakan musik hanya dilakukan Jonet ketika pentas saja. Hal yang bisa didapatkan dari pengalaman berlatih menari dengan Waluyo adalah kedisiplinan dalam menari 
dan melatih kepekaan dalam iringan. (Sri Kuncoro, 2006: 1)

Mulai dari TK keinginan jonet untuk berlatih tari semakin besar. Jonet terus melanjutkan berlatih tari dengan Waluyo sampai kelas empat Sekolah Dasar (SD). Pada saat kelas lima SD Jonet masuk di Yayasan Kesenian Indonesia (YKI). Terbenturnya biaya Jonet tidak bisa melanjutkan belajar di YKI, sehingga Jonet mulai berlatih menjadi pemain wayang orang Sriwedari, pada saat itu jika ada wayang orang Sriwedari yang mengambil cerita anak kecil jonet dijadikan tokoh Abimanyu Karen (Gathutkaca kecil).

Jonet lulus dari SD pada tahun 1977 dan melanjutkan sekolah tinggi lagi di Sekolah Menengah Pertama Muhamadiyah 1 Surakarta dan lulus pada tahun 1980. Pada saat kelas enam SD hingga kelas dua SMP jonet sempat berhenti tidak berlatih tari karena dia diikutkan oleh seorang pedagang di Kartasura untuk meringankan beban orang tuanya.

Waktu terus berjalan seiring keinginan jonet untuk belajar tari yang semakin kuat. Keinginannya yang demikian besar, maka diputuskannya untuk belajar tari dipendidikan formal yaitu Sekolah Menengah Kesenian Indonesia (SMKI) Surakarta pada tahun 1980 selama empat tahun dan setelah lulus dilanjutkannya lagi untuk memasuki perguruan tinggi seni yaitu Akademi Seni Karawitan Indonesia (ASKI) Surakarta pada tahun 1983, serta berlatih dengan empu tari Surakarta yaitu S. Mariidi sebagai guru dari gaya tari Kasunanan, Rono Suripto sebagai guru tari gaya Mangkunegaran, Radiyono dan Suwardi. Tidak hanya mendapatkan materi tari, namun juga banyak hal yang didapatkan misalnya cara tehnik mengajar mereka.
Diantaranya dalam memberi contoh bentuk gerak, S. Maridi melakukan dengan sungguh-sungguh, teliti, dan disiplin, selain itu dalam hal waktupun juga sangat disiplin. Hal ini dapat dilihat dari kedisiplinan ketika mengajar tari, S. Maridi selalu hadir tepat waktu, bahkan sering kali datang lebih awal.

Memasuki semester VII di ASKI Surakarta, setiap mahasiswa diwajibkan untuk mengikuti program kuliah kerja nyata (KKN). Pengalaman jonet untuk mengenal tentang anak dimulai dari program KKN ini. Jonet ditugaskan untuk mengajar tari di kecamatan Laweyan, Surakarta. ASKI memberitahukan bahwa akan diadakan lomba Tari Merak dan wanoro sehingga ketika pembekalan KKN Jonet juga dibekali pelatihan Tari Merak dan Wanoro karena di ASKI tidak ada materi pembelajaran yang materinya tari anak-anak. Hal ini semakin menambah bekal Jonet dalam pengkayaan materi anak-anak, karena sebelumnya Jonet sudah bisa tari anak-anak seperti Kukila, Kidang, Pangpung, dan Merak.

Jonet mulai melaksanakan KKN menghadapi masyarakat dan sekolahsekolah. Beberapa sekolah yang dijadikan tempat mengajar ketika KKN adalah SD 15, SD Purwotomo, dan SD Karangasem. Dari tempat inilah Jonet lebih dapat memahami dan mengenal tentang anak-anak. Di sini pulalah pengalaman mengajar Jonet juga terbangun dalam hal menyusun karya tari dan memahami anak-anak.

Pada tahun 1988 Jonet berhasil lulus dari Sekolah Tinggi Seni Indonesia (STSI) Surakarta dan diangkat sebagai pegawai negri sipil (PNS) sebagai pengajar jurusan seni tari di STSI Surakarta pada tahun 1990. Adanya pengalaman yang dimilikinya, Jonet terus menerus melatih anak-anak 
sampai pada akhirnya tahun 1993 Jonet ditawari G,P.H Herwasto Kusumo yang lebih dikenal dengan Gusti Heru untuk mengajar di Sanggar Soeryo Soemirat hingga saat ini.

Pengalaman Jonet sebagai penari dan koreograer semakin bertambah ketika Ia mengikuti pementasan tari baik di dalam negri maupun di luar negri, sebagai penari maupun sebagai koreografer.

\section{KOREOGRAFI KARYA TARI AMBABAR BATIK}

Tari Ambabar Batik merupakan salah satu tari kreasi gaya Surakarta, dikataan kreasi karena tari Ambabar Batik dalam gerak tarinya menggunakan gerak-gerak dasar tari gaya Surakarta yang kemudian dikembangkan oleh koreografernya.

Karya tari Ambabar Batik disusun oleh Jonet Sri Kuncoro pada tahun 2007. Tari ini merupakan tari yang dibuat untuk keperluan Festival Parade Tari Nusantara yang diadakan di Taman Mini Indonesia Indah. Karya Tari Ambabar Batik merupakan sebuah bentuk koreografi. Koreografi sendiri menurut Soedarsono berasal dari bahasa Yunani yaitu choreia yang artinya tari masal, dan grapho yang artinya pencatatan. Jadi koreografi adalah catatan mengenai tari. Namun dalam perkembangan, koreografi memiliki arti sebagai garapan tari atau dance composition (1977:33). Arti kata koreografi telah banyak dijelaskan didalam berbagai tulisan. Dalam Kamus Besar Bahasa Indonesia (KBBI) karta koreografi merupakan seni mencipta dan menggubah tari (Alwi,dkk, 2005:595).

Pengamatan koreografi dalam tari Ambabar Batik mengunakan konsep koreografi oleh Y. Sumandyo Hadi yang dalamnya terdapat beberapa elemen-elemen koreografi, diantaranya (1) judul tari; (2) tema tari; (3) deskripsi tari; (4) gerak tari; (5) ruang tari: (6) musik tari; (7) tipe atau jenis tari; (8) mode atau cara penyajian: (9) penari (jumlah,jenis kelamin); (10) rias dan kostum tari; (11) properti tari. Adapun penjelasan dari elem-elemen pada koreografi tari Ambabar Batik adalah, sebagai berikut.

\section{Judul Tari}

Pemilihan judul Ambabar Batik mennurut koreografer yaitu Jonet Sri Kuncoro diartikan sebagai bercerita tentang batik (Jonet Sri Kuncoro, Wawancara 4 September 2017). Menurut Jonet, penggunaan judul ini sangat pas dengan isi karya tari ini yang bercerita tentang motif-motif batik yang belum banyak diketahui masyarakat luas dan berharap karya tari ini bisa memberi wawasan kepada penonton tentang batik. Jonet mengambil pemilihan judul ini karena isi dari karya tari ini bercerita tentang batik dan menyampaikan nya kepada penonton melalui gerak-gerak yang telah disusun dalam karya tari ini, juga agar penonton lebih tertarik dan lebih mudah memahami apa yang akan disampaikan dalam karya tari ini.

Karya ini termotivasi atau bersumber pada Batik, dengan harapan dapat menempatkan batik sebagia proses pencapaian estetik dalam koreografi ini. Berkaitan dengan hal tersebut, pemberian judul Ambabar Batik tidak semata-mata hanya sebagai istilah atau ungkapan lisan saja. Menurut Jonet Sri Kuncorojudul tersebut lebih tepat dan pas untu dapat mengejawantahkan ide gagasan dalam penciptaan karya tersebut (Jonet Sri Kuncoro, wawancara 4 September 2017) 


\section{Tema Tari}

Tema Tari dapat dipahami sebagai pokok permasalahan yang mengandung isi atau makna tertentu dari sebuah koregrafi, baik bersifat literal maupun non literal (Hadi, 2003:89). Komposisi tari, yang berdasarkan tema yang digarap bahwasannya dapat dibedakan berdasarkan tema literal dn non literal. maka tema pada karya tari ini digolongkan sebagai literal. Dengan demikian, penyajiannya tidak menampilkan atau menggarap karakter tokoh tertantu, tetapi tetap menggunakan alur. karya ini hanya berpijak dari fenomena keadaan atau kondisi yang ada di Indonesia yang saat itu sedang mempromosikan tentang batik dikancah Internasional.

\section{Jenis Tari}

Untuk mengklasifikasikan jenis tari atau garapan koreografi dapat dibedakan misalnya klasik tradisional, tradisi kerakyatan, moderen atau kreasi baru, dan jenis tarian etnis. Dalam hal ini pendapat Smith yang dikutip oleh Sumandyo Hadi dalam buku Aspek-aspek dasar koreografi kelompok mengemukakan bahwa tipe atau jenis tari dapat dikelompokkan, misalnya: tipe murni (pure), studi (study), abstrak (abstract), liris (lyrical), dramatik (dramatic), komik (comic) dan tipe dramatari (drama-dance) (Hadi,2003:90). Berdasarkan penjelasan tersebut, maka karya tari Ambabar Batik merupakan jenius atau tipe dramatik ( $d r a-$ matic) krena sifat garap tarinya mengungkapkan fenomena nilai sosial kehidupan bermasyarakat. Menurut Jaqualine, yang telah diterjemahkan oleh Ben Suharto,

Tari dramatik mengandung arti bahwa gagasan yang dikomunikasikan sangat kuat dan penuh daya piket, dinamis, dan banyak ketegangan, dan demikian melibatkan konflik antara orang seorang dalam dirinya dengan orang lain. Tari dramatik akan memusatkan perhatian pada sebuah kejadian atau suasana yang tidak menggunakan cerita (Jaqualine Smith terj. Ben Suhharto, 1985:16).

Hal tersebut bersesuaian dengan tari Ambabar Batik yang tidak mengangkat alur cerita, namun lebih menekankan pada fennomena sebuah garapan tari walaupun pada karya ini ada satu orang penari yang nembang tetapi itu hanya untuk memperkuat suasan.

\section{Mode Penyajian}

Menurut tulisan Y. Sumandyo Hadi dalam bukunnya, mode atau cara penyajian (mode of presentation) koreografi pada hakekatnya dapat dibagi menjadi dua penyajian yang sangat berbeda, yaitu bersifat representasional dan simbolis (Hadi,2003:90). Karya Tari Ambabar Batik dapat dikategorikan sebagai tari dengan mode penyajian simbolis representasional karena karya tari Ambabar Batik ini tidak hanya menyajikan gerak yang hampir tidak bisa dikenali makna geraknya, akan tetapi ada juga beberapa gerakan-gerakan jelas dan dapat diidentifikasi makna geraknya atu artinya, meski keduanya memiliki porsi yang berbeda, karya tari Ambabar Batik ini banyak menyajikan gerak-gerak simbolis.

\section{Ruang Tari}

Unsur yang terkait dengan bentuk sajian karya tari Ambabar Batik selain gerak yaitu ruang. Ruang menurut Sumandyo Hadi adalah sebagai berikut:

Ruang adalah suatu yang tidak bergerak dan diam sampai gerakan 
yang terjadi didalamnya mengintrodusir waktu, dan dengan cara demikian mewujudkan ruang sebagai suatu bentuk, suatu ekspresi khusu yang berhubungan dengan waktu yang dinamis dari gerakan Ruang tari adalah latai tiga dimensi yang didalamnya seorang penari dapat mencipta suatu imaji dinamis. memerinci bagian-bagian komponen yang membawa banyak kemungkinan untuk mengeksplor gerak (2003:23)

Karya tari Ambabar Batik lebih banyak menggunakan aspek ruang positif, menurut Sumandyo Hadi bentuk ruang positif adalah ruang yang ditempati secara nyata oleh objek atau desain bentuk gerak, karena penari pada tari Ambabar Batik tidak hanya satu atau dua melainkan kelompok, sehingga ruang yang yang terlihat lebih dibentuk pada penari. Pola-pola lantai yang digunakan dalam karya tari Ambabar Batik adalah berbentuk pola lantai asimetris dan simetris dengan membentuk garis-garis, mengerombol, menyebar, sejajar, dan melingkar. Ruang pentas untukkarya tari Ambabar Batik ini disajikan lebih banyak dilakukan di pangung prosenium yang hanya bisa dilihat dari satu arah saja tetapi ada beberapa pementasan yang disjikan dipanggung arena yang lebih bisa dilihat dari berbagai arah oleh penonton.

\section{Gerak Tari}

Gerak merupakan medium pokok dari pengarapan sebuah tari, tari adalah ekspresi jiwa manusia yang diungkap dengan gerakgerak ritmis yang indah (Soedarsono, 1978:16). Penjelasan tersebut diperjelas dengan pendapat Srihadi bahwa: tari bahan utamanya adalah gerak, namun demikian gerak yang ditimbulkan oleh tubuh manusia belum bisa dikatakan gerak tari apabila tidak tergantung ritme/tempo, dan estetis serta mengandung makna didalamnya. Artinya yang disebut dengan gerak tari adalah gerak yang dibentuk oleh tubuh, memiliki makna dan dibalut dengan rasa estetis, serta memiliki ritme/tempo (Srihadi, 2014:110).

Gerak tari pada karya tari Ambabar Batik berpijak paada motif-motif gerak gaya surakarta. gerak yang ada di karya ini digarap dinamis, sederhana, lincah, dan menimbulkan garis-garis yang dinamis. Gerak-geraknya tidak terlalu rumit karna Jonet sadar bawa penarinya masih anakanak, Gerakannya dibuat sederhana tetapi tetap lincah dan menarik agar kesan bermain yang sering dilakukan anak-anak terlihat didalam karya tari ini.

Gerak dalam karya tari Ambabar Batik digarap sesuai dengan tema yang telah ditentukan. Vokabuler geraknya dihasilkan dari eksplorasi terhadap beberapa motiv gerak. Gerak dalam Ambabar Batik terbagi menjadi tiga jenis macam gerak, yaitu motif gerak, gerak transisi dan gerak pengulangan, hal ini sesuai dengan konsep yang dikemukakan oleh Y. Sumandyo Hadi dalam bukunya.

Menurut Sumandyo Hadi gerak dalam sebuah elemen koreografi dibagi menjadi tiga yaitu: motif gerak, gerak penghubung dan gerak pengulangan. Motif gerak itu adalah eksperiman dari beberapa gerak menjadi sebuah motif gerak. Gerak penghubung atau transisi merupakan gerak yang digunakan sebagai perpindahan dari vokabuler satu ke vikabuler gerak yang lain. Pada karya ini gerak transisi atau perpindahannya menggunakan variasi gerak srisik, dan memutar. Gerak pada karya tari Ambabar Batik ini juga lebih cenderung pada 
gerak yang bertempo sedang ke cepat, bervolume besar untuk membangun suasana.

Tari Ambabar Batik tidak hanya bergerak, tetapi ada sebuah proses stilisasi dari sebuah proses gerak, dari situlah muncul sebuah koreogarfi hingga muncul karakter secara global.Tidak ada nama-nama khusus dalam unsur-unsur gerak dalam tari Ambabar Batik, karena vokabulernya mengacu pada terjemahan dari bentuk itu. Motif gerak pada karya tari Ambabar Batik diantara yaitu motif gerak putri gaya surakarta, motif gerak srisikan, Motif gerak dolanan bocah, dan motiv gerak mengolah properti, dengan gerak transisi srisik dan memutar dengan variasi sesuai dengan kebutuhan. Pemberian nama pada motif gerak ini sudah dikonfirmasikan kepada koreografer, untuk mempermudah analisis dalam gerak.Gerak pengulangan terjadi pada motif gerak dolanan dan mengolah properti.

\section{Musik Tari}

Musik tari dalam penyajian tari memiliki peran yang sangat penting di dalamnya. Seperti yang dikatakan Soedarsono bahwa bahwa musik yang ada didalam tari bukan hanya sebagai iringan saja, namun musik didalam sebuah tarian merupakan satu kesatuan yang tidak dapat dipisahkan (Soedarsono 1997:46). Sementara itu Sumandyo Hadi menjelaskan bahwa fungsi musik dalam tari dapat dipahami sebagai iringan ritmis gerak tarinya, dan sebagai ilustrasi suasana tarinya, atau dapat terjadi kombinasi kedua fungsi itu sebagai harmonis (Hadi 2003:88).

Musik tari sebagai ilustrasi dibutuhkan untuk membangun suasana tari. Karya tari Ambabar Batik mengunakan musik yang digarap oleh Antonius Wahyu Sutresno atau akrab disapa Dedek Wahyudi. Garap musiknya pun sangat berbeda dengan garap musik karawitan atau gamelan jawa pada umumnya. Garap musik pada karya tari Ambabar Batik ini menggunakan gendhing Ilir-ilir yang dimodifikasi karena berhubungan dengan makna simbolik yang ada didalam teks syair gendhing Ilir-ilir itu sendiri. (Wawancara, Dedek Wahyudi, 18 november 2017) Susunan melodi dalam musik tari karya tari Ambabar Batik ini juga khusus dibuat untuk kebutuhan karya ini saja dan tidak ada dikarya tari yang lain, ini juga menjadi ciri khas dari karya tari Ambabar Batik karya Jonet Sri Kuncoro. Materi pokok dalam garapan musik ini dirasa sangat cocok dengan ide garap koreografer. Ciri khas nya itu sendiri terdapat pada permainan pada melody gender, bonang, dan suling, itu yang membedakan aransemen pada musik karya ini dengan musik yang lainnya.

Urutan sajian dalam aransemen musik Ambabar Batik ini adalah sebgai berikut: bagian awal introduction, bagian kedua tembang pocung, bagian ke tiga gendhing ilir-ilir, bagian akhir komposisi bonang.

Dalam perkembangan nya setiap karya tari Ambabar Batik pentas untuk musik tarinya tidak ada perubahan dari segi gendhing yang digunakan maupun susunan nya hanya saja komposer menggunakan orkes gamelan tetapi juga mempertibangkan tempat dan arahan dari koreografer (Dedek Wahyudi, wawancara 18 November 2017)

\section{Penari (jumlah dan jenis kelamin)}

Penari adalah sarana yang penting dalam terwujudnya suatu karya tari, penari mempunyai andil besar dalam mengungkap bentuk dan isi tari. Tersampaikan 
atau tidaknya bentuk sajian isi dari sebuah karya tari tergantung bagaimana seorang penari memiliki tubuh sebagai instrumen atau alat yang didalamnya memiliki kemampuan daam menyampaikan suatu karya tari.

Pada karya tari Ambabar batik, Jonet menggunakan sembilan penari perempuan yang berumur kurang lebih sebelas tahun. Penari-penari tersebut yaitu; Marshalia Rose Fajaringsih, Sianita Arighi, Mintari Astuti, Arsie Noor Rafidah, Siska Kusuma Ningrum, Asri, Damar Sari Tri Atmani, Riski Dewayani, Elvanya Pribadita mereka tergabung dalam sanggar tari Soeryo Soemirat sebagai siswa.

Alasan Jonet memilih penari perempuan di karya tari Ambabar Batik ini adalah karena kembali pada fenomena yang ada bahwa yang membatik itu biasanya dilakukan oleh para perempuan dan itulah yang menjadi pertimbangan kenapa koreografer memilih penari peremmpuan, dan untuk jumlah penari alassan berjumlah sembilan pada pentas yang dilaksnakan di TMII Jakarta karena penari yang berjumlah sembilan orang diangap ideal dan cukup untuk memunculkan sebuah fenomena yang diangkat dengan konfigurasi-konfigurasi yang menarik, tetapi daam karya ini tidak harus sembilan penari yang menarikan tetapi dapat berubah sesuai kebutuhan panggung.

Menurut salah satu penari yaitu Marshalia rose dalam menyajikan karya tari ini bukan hanya dituntut hafal gerak tetapi bagaimana ia menari juga sambil nembang dan harus lincah karna gerakan-gerakan yang ada di karya ini menurutnya tidak mudah dilakukan anak yang masih berumur sebelas tahun pada saat itu (Marshalia Rose, wawancara 12 Oktober 2017).

\section{Rias dan Kostum Tari}

Tata rias dan busana di dalam sebuah penyajian pertunjukan tari sangat penting, karena di dalam penyajian tari peran rias dan kostum harus mendukung penampian. Menurut Mugiyanto tata rias dalam sebuah seni pertunjukan diperlukan untuk memberikan tekanan atau aksentualisasi bentuk dan garis-garis wajah sesuai dengan tuntutan karakter tariannya (1992:144).

Dalam karya Tari Ambabar Batik ini menggunakan rias wajah yang sederhana hanya menggunakan make up wajah yang membuat wajah para penarinya tampak lebih segar dan tidak menonjolkan karakter khusus. Selain rias wajah, untuk tatanan rambut yang digunakan pada karya tari ini ialah dengan cara di kepang tekuk karena koreografer ingin mengembalikan busana dan tatanan rambut ke jaman anak-anak keraton dahulu.

Menurut Murgiyanto, pemilihan warna kostum tari, dismping ditentukan oleh isi tarian, juga dipengaruhi oleh warna atar belakang, wujud latar, serta penataan cahayanya (Murgiyanto, 1992:111). Tata busana yang digunakan dalam karya tari Ambabar Batik menggunakan kemben semekan dan jarik sabuk wolo yang berwarna warni pada setiap penarinya. Adapun perbedaan warna tersebut disesuaikan dengan konsep garapan dari karya tari Ambabar Batik itu sendiri yang ceria, dinamis dan menarik. Perbedaan warna pada busana yang digunakan juga terinspirasi dari kembang setaman karena walaupun warna nya berbeda-beda tetapi tetap menjadi satu rasa yang kuat. Pemilihan bentuk kemben dan jarik juga mempunyai tujuan tertentu, yaitu kooregrafer ingin mengembalikan suasana pada jaman anak-anak keraton 
dahulu yang menggunakan kemben dan jarik model sabuk wolo.

\section{Tata Cahaya}

Penggunaan tata cahaya dalam pertunjukan karya tari Ambabar Batik ini hanya menggunakan satu lampu saja yaitu lampu general. Menurut pendapat Sumandyo Hadi, seperti halnya rias dan busana atau kostum, peranan tata cahaya sangat mendukung suatu bentuk pertunjukan tari (Hadi, 2003:92).

Karya tari Ambabar Batik ini hanya menggunakan lampu general light karena dalam karya tari ini menggambarkan keceriaan, senang, dan kesederhanaan.

\section{Properti Tari atau Perlengkapan Lainnya}

Properti yang digunakan dalam karya tari Ambabar Batik ini adalah kain batik yang bermotif antara lain, yaitu: parang klithik, parang rusak, parng barong, parang kusumo, sido luhur, sido mulyo, sido mukti, wahyu tumurun, motif-motif batik inilah yang paling sering digunakan oleh masyarakat, tujuannya memilih motif batik ini agar karya tari ini mudah dimengerti dan dipahami karena motif-motif batiknya sudah familiar dengan masyarakat (Jonet Sri Kuncoro, wawancara22 November 2017).

\section{KREATIVITAS JONET SRI KUNCORO}

Kreativitas dapat berupa kombinasi baru, berdasarkan data, informasi, atau unsur-unsur yang sudah ada atau dikenal sebelumnya, yaitu semua pengalaman dan pengetahuan yang telah diperoleh seseorang selama hidupnya baik iitu dilingkungan sekolah, keluarga, maupun dari lingkungan masyarakat (Munandar 2009: 12)
Dengan lain kata kreativitas merupakan suatu proses berpikir yang lancar, lentur, dan orisinal dalam menciptakan suatu gagasan yang bersifat unik, berbeda, orisinal, baru, indah, efisien, dan bermakna, serta membawa seorang berusaha menemukan metode dan cara baru didalam memecahkan suatu masalah.

Pribadi kreatif Jonet dipandang sebagai seorang yang mampu menterjemahkan ide gagasannya melalui pengalaman empirik menjadi hal yang inovatif. Tindakan kreatif muncul dari keunikan keseluruhan kepribadian dalam interaksi dengan lingkungannya. Salah satu faktor yang harus dimiiki oleh seorang koreografer didalam menciptakan sebuah karya tari adalah sifafat kreatif. Menurut pendapat Rhodes yang dikutip oleh Munandar, bahwa definisi tentang kreativitas sering disebut dengan Four P's Creativity: Person, Press, Process, Product (2002:26). Kreativitas itu sendiri dapat dijelaskan melalui pribadi, pendorong, proses dan produk yang dihasilkan. Berdasarkan penjelasan tersebut karya tari Ambabar Batik ini dijelaskan melalui konsep 4P tersebut. Konsep 4P tersebut, menjelaskan tentang adanya hubungan antara keempat hal tersebut yaitu pribadi, pendoorong, proses, dan produk.

\section{Pribadi (Person)}

Hal yang diangap penting didalam keberhasilan kreativitas dari serang koreografer adaah pribadi atau person. Dalam hal ini Jonet Sri Kuncoro secara pribadi sebagai seorang koreografer dipengaruhi oleh bakat, pengalaman dan juga lingkungannya. Pribadi seorang Jonet sri kuncoro dapat dilihat dari hasil-hasil karya tari yang diciptakan 
berdasarkan pengalaman pribadi tehadap kehidupn bermasyarakat saat ini. Jonet Sri Kuncoro didalam setiap karyanya dikenal sebagai koreografer yang produktif dalam hal berkarya.

Pribadi dari Jonet Sri Kuncoro memiliki intelegensi atau kemampuan dalam menciptakan dan menyusun tari. telah dijelaskan sebelumnya dalam kesenimanan Jonet Sri kuncoro bahwa ia mulai mempelajari dunia seni khususnya seni tari, yaitu mulai ia kecil. Keinginannya untuk menjadi seniman profesional merupakan dorongan yang kuat dan sangat berpengaruh dalam pengembangan pribadinya. Pengembangan pribadi Jonet Sri Kuncoro berdasarkan pengalaman yang telah didipatkan menjadikan pribadi yang lebih bijak dalam menyikapi suatu fenomena budaya yang terjadi.

\section{Pendorong (Press)}

Pendorong atau motivasi dalam mellakukan kreativitas terdiri dari dua faktor internal dan eksternal. Hal ini sama dengan pendapat Munandar bahwa pendekatan terhadap kreativitas menekankan faktor pendorong (press) atau dorongan, baik dorongan internal yaitu dari diri sendiri maupun dorongan eksternal dari lingkungan sosial dan pisikologis (Munandar,2002:23).

a. Faktor Internal

Faktor internal merupakan faktor yang merupakan pendorong berasal dari dalam diri seorang koreografer tersebut. Faktor internal dari dalam diri diri Jonet Sri Kuncoro dalam menggarap karya tari Ambabar Batik adalah keinginan besar untuk mencipta yang dipengaruhi faktor dari dalam yaitu modal Jonet Sri Kuncoro sebagai penari, Koreografer serta dosen tari, dan juga kecintaan Jonet Sri Kuncoro terhadap dunia anak-anak.

Keinginannya yang kuat untuk menjadi seorang koreografer dan penari profesional juga salah satu faktor pendorong dari dalam dirinya. Keinginannya dapat terwujud berkat kerja keras dan ketekunannya selama ini. Selain itu juga didukung pula oleh kemampuan tari yang terdapat pada dirinya dan dikembangkan sejak itu ia masih kecil.

\section{b. Faktor Eksternal}

Selain faktor internal, faktor eksternal juga mendorong Jonet Sri Kuncoro menyusun karya tari Ambabar Batik. Faktor eksternal yang mempengaruhi Jonet Sri Kuncoro dalam menciptakan karya tari Ambabar Batik ini adalah permintaan dari pemerintah provinsi Jawa Tengah untuk mewakili dalam acara Festival Tari Nusantara yang diadakan di Taman Mini Indonesia Indah (TMII) Jakarta. Festival ini lah menjadi awal karya tari Ambabar batik ini tercipta. Fenomena yang diambil dalam karya tari ini tentu saja adalah batik, alasan memeilih fenomena batik ini adalah karena pada saat itu pemerintah indonesia sedang gencar mensosialisasikan tentang batik kepada masyarakat, dari situlah karya tari ini tercipta dengan ide yang mengambil dari fenonena yang ada di lingkungan masyarakat Indonesia.

\section{Proses Kreatif}

Proses Kreatif seorang koreografer dapat juga diawali dengan proses melihat didalam mencipta suatu karya, suatu karya yang diciptakan berbeda-beda dan tergantung dari pengalaman masing-masing baik pengalaman pribadi atau fenomena- 
fenomena yang terjadi disekitar lingkungan tempat tinggal dan kepekaan yang tidak ingin ditinggalkan begitu saja. Sehubungan dengan hal tersebut, Soedarsono megungkapkan bahwa pada dasarnya manusia mencari pengalaman kreatif dan pengalaman-pengalaman estetis, karena dari pengalaman tersebut manuasia dapat memperkaya pengalaman yang ada pada dirinnya. Proses melihat yang dikatakan sebelumnya dapat menjadi awal sebuah proses kreatif seorang koreografer. Melalui pengalaman kreatif dan pengalaman estetis, koreografer bisa menjadi seorang yang berintegrasi dan membantu penyusun tari merasa nyaman dengan dunianya (1978:38).

Proses kreatif Jonet Sri Kuncoro dimulai dari meliht fenomena yang ada disekitar lingkungannya, yang artinya permasalahan yang diangkat adalah bagaimana kondisi fenomena yang ada disekitarnya. Karya tari Ambabar Batik ini melalui beberapa tahap penciptaan.Menurut pendapat Alma Hawkins yang dikuutip oleh Soedarsono bahwa pengalaman-pengalaman tari yang memberi kesempatan dan membantu membagi perkembangan kreatif dapat diklarifikasikan menjadi tiga yaitu: Eksplorasi, Improvisasi, serta kompsisi.

\section{a. Eksplorasi}

Eksplorasi adalah kegiatan berfikir, berimajinasi, merasakan dan merespon (Hawkins, 1990:27).Eksplorasi adalah kegiatan awal seorang koreografer didalam mencipta suatu karya. Langkah awal yang dilakukan adalah dengan melakukan eksplorasi gerak berdasarkan tema yang diangkat dalam karya tari Ambabar Batik adalah fenomena batik yang pada saat itu sedang di promosikan di kancah dunia (Jonet Sri Kuncoro, wawancara 22 november 2017). Eksplorasi gerak dilakukan oleh Jonet Sri Kuncoro, secara keseluruhan menerjemahkan tentang bagaimana para pembatik pada saat itu sedang membatik sambil bercengkrama dengan teman-temannya, hingga nembang bersama dan mengenalkan corak-corak batik kepada masyarakat. Suasana tersebut dimunculkan Jonet Sri Kuncoro pada bagian awal sampai akhir pada karya tari ini, sehingga karya tari Ambabar Batik ini pada akhirnya setelah melakukan eksplorasi, polapola gerak yang lincah dan atraktiv juga pola lantai yang membentuk garis-garis yang tajam.

\section{b. Improvisasi}

Improsisasi merupakan tahap selanjutnya yang dilakukan oleh seorang koreografer di dalam menciptakan sebuah karya tari Ambabar Batik.Soedarsono mengatakan bahwa improvisasi bila digunakan secara bijaksana dapat merupakan suatu cara yang berharga bagi peningkatan pengembangan kreativitas (Soedarsono, 1978:40).

Berdasarkan motif gerak yang didapat dari proses eksplorasi selanjutnya Jonet Sri Kuncoro mengembangkannya kembali sehingga menjadi lebih menarik. Pada saat pertemuan awal latihan karya tari ini Jonet Sri Kuncoro menjelaskan kepada para penari tentang ide garapannya dalam karya ini, selanjutnya menceritakan tentang apa tarian yang akan digarap tersebut, selanjutnya Jonet Sri Kuncoro memberikan beberapa contoh gerakan yang digunakan pada karya tari Ambabar Batik dan ditirukan oleh para penari. 


\section{c. Komposisi}

Komposisi merupakan tahap selanjutnya setelah tahap eksplorasi dan improvisasi. Tujuan dari akhir di dalam pengalaman yang diarahkan sediri adalah mencipta karya. Proses ini disebut dengan proses membuat komposisi (composing atau forming). Menurut pendapat Soedarsono kebutuhan membuat komposisi lahir dari hasrat menusia untuk memberikian bentuk kepada apa yang ia tentukan. Spontanitas masih penting tetapi pada spontanitas ditambah dengan proses pemilihan, pengintergrasian, dan penyatuan (Soedarasono, 1978:41). Komposisi ini sering disebut sebagi seluruh rangkaian proses yang dilakukan koreografer dalam mencipta sebuah karya tari. Dari proses tersebut muncul bentuk-bentuk karya tari yang bersifat ekspresif dan unik dari penciptanya. Selanjutnya Jonet Sri Kuncoro menyusun seluruh gerakan yang dihasilkan dari tahap eksploraasi dan improvisasi. Penyusunan gerak sangat diperhatikan oleh Jonet Sri Kuncoro agar dalam penyajiannya sesuai dengan apa yang diharapkan.

Pada akhirnya karya tari Ambabar Batik tercipta setelah mengalami beberapa proses. Jonet Sri Kuncoro dalam penyusunan karya tari Ambabar Batik dengan pola kerja keras di dalam berproses selalu ingin mendapatkan hasil ynng sesuai dengan yang dihrapan.

\section{Produk (Product)}

Definisi tentang Product ialah hasil akhir dari proses kreatif. Produk yang dihasilkan oleh Jonet Sri Kuncoro dalam hal ini yaitu karya tari Ambabar Batik. Definisi mengenai pengertian produk kreatif yaitu adanya unsur orisinalitas dan kebaruan dari karya trsebut. Karya tari Ambaar Batik adalah karya tari yang sebelumnya belum pernah ada yang menciptakan meskipun materi gerak yang digunakan dalam karya tari ini mengambil dari gerak-gerak tari gaya surakarta. Hefele juga menekankan bahwa suatu produk kreatif tidak hanya harus baru tetapi juga diakui sebagai bermakna.Produk kreatif adalah hasil akhir dari kreativitas yang didalamnya terdapat unsur orisinalitas dan kebaruan dalam karya tersebut (Munandar, 2002:28). Karya tari Ambabar Batik merupakan produk kreatif yang didalamnya terdapat keorisinalitas yang berupa ide penyusunan yang berdasar pada fenomena batik sebagai dasar penyusunan

Karya tari Ambabar Batik merupakan produk kreativitas dari Jonet Sri Kuncoro yang memiliki kualitas unik individu berdasar pada interaksinya dengan lingkungan. Keunikan dari karya tari Ambabar Batik adalah berada pada susunan musik tarinya dan pada kulitas penarinya yang dalam menyajikannya dengan cara nembang sambil menari (Jonet Sri

Kuncoro, wawancara 22 November 2017). Kemudian penentuan dari proses kreatif menyangkut pribadi atau person, selanjutnya proses itu sendiri dan produk kreatif. Product yang dihasilkan dari proses kreatif sebagai kriteria kreativitas maka produk tersebut diangap sebagai produk kreatif dan orangnya disebut orang kreatif. Karya tari ini termasuk karya tari yang berhasil, terbukti karya tari ini sudah dipentaskan diberbagi kota dan mendapat pengakuan dari masyarakat lingkungan luas. Karya tari Ambabar Batik merupakan produk yang nyata dan memiliki kualitas unik individu berdasarkan interaksinya. 


\section{PENUTUP}

Karya Tari Ambabar Batik merupakan tari kelompok yang terinspirasi dari corakcorak kain batik. Pengarapan koreografi tari ini memiliki keunikan dari segi musik tarinya maupun dari koreografinya. Karya tari Ambabar Batik ini merupakan perwujudan dari Jonet Sri Kuncoro dalam melihat suatu fenomena yang selanjutnya dituangkan dalam bentuk karya tari. Terciptanya karya tari Ambabar Batik meruppakan perwujudan dari keinginan Jonet Sri Kuncro yang sangat kuat dalam mengkaji lenbih dalam tentang batik. Jonet Sri Kuncoro sebagai penari, koreografer dan pengajar telah mengalami berbagai macam pengalaman yang berhubungan dengan dunia seni khusunya tari. Gerak pada karya tari ini menggunakan tempo sedang ke cepat dan bervolume besar untuk membangun suasana. Tidak ada nama-nama khusus dalam unsur-unsur geraknya, karena vokabuernya itu mengacu ke terjemahan dari bentuk itu. Karya Jonet Sri Kuncoro ini termasuk dalam koreografi kelompok yang memiliki elemen-elemen yang terkait tidak lepas dari pembentukan gerak. Kreativitas Jonet Sri Kuncoro dalam karya Ambabar Batik didasari oleh adanya Festival parade Tari Nusantara yang diadakan di Taman Mini Indonesia Indah Jakarta pada tahun2007.

Pengarapannya tidak lepas dari kreativitas Jonet Sri Kuncoro sebagai koreografer serta para pendukungnya dengan metode penggarapan melaalui observasi, eksplorasi, Improvisasi dan komposisi.

\section{DAFTAR PUSTAKA}

Alwi, Hasan, dkk. 2001/1998. Kamus Besar Bahasa Indonesia. Jakarta: Balai Pustaka.

Amelia, Riva.

2017. “Aku Bisa Karya Jonet Srikuncoro Dalam Ketubuhan Kaum Difabel Tunarungu Di SDLB N Dan SMPLB Bina Karya Insani Cangakan Karanganyar." Skripsi S1 Jurusan Tari Fakultas Seni Pertunjukan Institut Seni Indonesia, Surakarta.

Fadhila, Royani Lathifa.

2016 "Kreativitas Penciptaan Tari Srimpi Srimpet Karya Sahita." Skripsi S1 Jurusan Tari Fakultas Seni Pertunjukan Institut Seni Indonesia, Surakarta.

Hadi, Y. Sumadyo.

2003 Aspek-Aspek Dasar Koreografi

Kelompok. Yogyakarta: ELKAPHI

Hadi, Y. Sumandyo.

2002 Fenomena Kreativitas Tari Dalam Dimensi Sosial Mikro. Surakarta

Hapsari, Fani Dwi.

"Kreativitas Boby Ari Setyawan Dalam Karya Tari Hanacaraka." Skripsi S1 Jurusan Tari Fakultas Seni Pertunjukan Institut Seni Indonesia, Surakarta.

Kartodirjo, Sartono.

1993 Pendekatan Ilmu Sosial Dalam Metodologi Sejarah. Jakarta: PT. Gramedia Pustaka Utama.

Kuncoro, Jonet.

2006 "Sebuah Catatan Harian". Tesis S-2 Program Studi Penciptaan Seni Fakutas Pasca Sarjana Institut Seni Indonesia, Surakarta. 


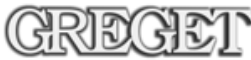

Munandar, Utami.

2002 Kreativitas dan keberbakatan strategi mewujudkan kreatif dan bakat, Jakarta:

Gramedia Pustaka Utama.

Murgiyanto, Sal.

1993. Ketika Cahaya Merah Memudar,Jakarta:

Deviri Ganan.

SD, Humardani. kumpulan kertas tentang tari. ASKI Surakarta. 1979/1980.

Sedyawati, Edy.

1981. Pertumbuhan Seni Pertunjukan. Penerbit Sinar Harapan

Soedarsono SP.2006. Trilogi Seni. Jogjakarta: BP ISI Jogjakarta

Supriyadi, Dedi.

1994. Kreativitas,Kebudayaan dan Perkembangan IPTEK. Jakarta: CV. Alfabetha.

\section{NARASUMBER}

Antonius Wahyudi Sutresno. (57 tahun), komposer dan Dosen karawitan ISI Surakarta. Ngringgo Indah, Jaten, Karanganyar.

Jonet Sri Kuncoro. (54 tahun), Koreografer dan Dosen tari ISI Suraarta. Perum Triagan Regency I, Mojolabban Sukoharjo.

Marshalia Rose Fajaringsih. (22 tahun), Penari dan siswa sanggar tari Soeryo Soemirat. Ngringgo Indah,Jaten, Karanganyar.

Sianita Arighi. (22 tahun), penari dan siswa sanggar tari Soeryo Soemirat. Sido Mulyo, Banyu Agung, Surakarta. 